\title{
Vaccine resistant pseudorabies virus causes mink infection in China
}

\author{
Gui-sheng Wang ${ }^{1,2}$, Yijun Du ${ }^{3}$, Jia-qiang $W^{3}$, Fu-lin Tian ${ }^{1}$, Xue-jie Yu ${ }^{4}$ and Jin-bao Wang ${ }^{2^{*}}$
}

\begin{abstract}
Background: Pseudorabies, a highly contagious infectious disease of swine is caused by pseudorabies virus (PRV). PRV can cause fatal infection in other animal species.

Results: We report a deadly outbreak of pseudorabies that killed 87.2\% (3522/4028) minks in a farm in 2014 in Shandong Province, China. PRV was isolated by using Vero cell culture and detected in mink samples by PCR from minks died during the outbreak. Epidemiological analysis indicated that 5.8\% of minks (33/566) were PCR positive to PRV in Shandong Province. Phylogenetic analysis indicated that the PRV strains isolated from minks in this study were in the same clade with the Chinese porcine PRV isolates, which are resistant to the PRV vaccine.

Conclusions: We demonstrated that pseudorabies virus caused an outbreak of minks in a farm in Shandong Province of China and the virus has a very high infection rate in minks in Shandong Province, which is a challenge for the fur industry in China.
\end{abstract}

Keywords: Minks, Pseudorabies, Pseudorabies virus, Herpesvirus, China

\section{Background}

Pseudorabies, also known as Aujeszky's disease, is caused by pseudorabies virus (PRV), a herpesvirus of genus Varicellovirus in the family Herpesviridae. PRV causes diseases in domesticated and wild animals, but only swine is considered as the reservoir and animal host of PRV because swine are the only animal species that can survive an acute infection and have a latent infection $[1,2]$. Like other alphaherpesviruses, in its natural host swine, PRV first invade epithelial cells of the mucosal surfaces, then the termini of nerve fibers, and finally the peripheral ganglia and the central nervous system to establish latent infection. In piglets or immunocompromised pigs, the nonspecific immune response is delayed or ineffective and the virus spreads through the central nervous system to cause abortion in pregnant swine and high mortality rates in piglets [2-4].

Due to its serious impact on the pig industry, some countries have tried to eradicate pseudorabies in commercial swine population based on the DIVA (differentiating infected from vaccinated individuals) vaccination

\footnotetext{
* Correspondence: 578005428@qq.com

${ }^{2}$ School of Life Sciences, Shandong University, 27 Shanda Road South, Jinan 250100, China

Full list of author information is available at the end of the article
}

program [5]. Pseudorabies has been eradicated in a few developed countries including the United States, several European countries and New Zealand [6-9]. Although the DIVA vaccination programs have been used in China, pseudorabies has reemerged since 2011 in China with increased infection frequency and severity in swine and other animals [10]. In recent years, a highly virulent PRV strain appeared in China that caused high mortality rates in grown pigs $[4,9]$. The new PRV variant is resistant to vaccine immunization in vaccinated swine herds in many regions of China [10].

PRV can infect a broad range of domestic and wild animals with the exception of higher-order primates [11]. The hallmark of the PRV infection in non-porcine animal species is pruritus in the infected area and it is usually fatal PRV-infected mink exhibit neurological signs and die within a few days without pruritus [12].

PRV genome is a linear double-stranded DNA, approximately $150 \mathrm{~Kb}$ with capacity to encode approximately 70 proteins [13]. PRV genome consists of a unique long region (UL) and a unique short region (US). The US region is bracketed by inverted repeat sequences, resulting in the formation of two possible PRV genome isomers with oppositely oriented US regions [13]. PRV major protective antigens including gB, gC, 
$\mathrm{gD}$, and $\mathrm{gH}$ can stimulate animals to produce viral neutralization antibody and cellular immunity against the virus [14]. gE and TK genes are major PRV virulence genes. gE mediates cell fusion, virus diffusion between cells, and virion releasing and neurotropic tropism. It is also a marker gene to distinguish natural infection from vaccination since the vaccine lacks the gE gene. TK plays important roles in viral infections in the body and viral proliferation in nervous tissue. Although PRV infects several animal species, reported natural PRV infection of minks are rare $[15,16]$. In September of 2014,3522 of 4028 minks died in 1 week in a farm in Shandong Province, China with $100 \%(3522 / 3522)$ case fatality and $87.2 \%(3522 / 4028)$ mortality. The clinical symptoms of the minks were sudden onset of pneumonia like syndroms, diarrhea and lethargy. Minks started to die 2 days after onset of illness and all of the dead minks died within a week. In this study, we studied the pathogen that caused the outbreak in minks in China.

\section{Methods}

\section{Mink samples}

We randomely seleted 10 dead minks during the outbreak from the farm to determine the causative agent. After the outbreak of mink infections on the intial farm, we obtained samples of 566 dead minks in 14 farms from 14 cities in Shandong Province to determine the ditribution and infection rate of the causative agent in minks in Shandong Province (Fig. 1). Sample size was determined according to a 95\% confidence level and 10\% PRV infection rate. The organs of the dead minks including heart, liver, spleen, lung, kidney, brain and intestine were collected from dead minks aseptically and were homogenized using metal beads (Tissue Lyser; Qiagen) in the RLT buffer (Qiagen).

\section{DNA and RNA extraction}

Two hundred microliters of homogenized mink tissue supernatant from each organ was used for total nucleotide extraction with the MiniBEST Viral RNA/DNA Extraction Kit (Takara, Dalian, China) in accordance with the manufacturer's protocol. The nucleic acid templates were stored at $-80{ }^{\circ} \mathrm{C}$ until use.

\section{PCR and RT-PCR amplification and DNA sequencing}

All the mink organs obtained above were tested for pseudorabies virus, influenza virus, parvovirus, rotavirus and porcine circovirus with PCR or RT-PCR. Porcine circovirus was amplified as previously described [17]. Pseudorabies virus, influenza virus, parvovirus, and rotavirus virus were amplified by using kit for each virus from Beijing Anheal Laboratories Co (Beijing, China) following the protocols of the manufacture.

For isolated strains of PRV, 6 genes including gB, gC, $\mathrm{gD}, \mathrm{gE}, \mathrm{gH}$ and $\mathrm{TK}$ were amplified by PCR (Table 1 ). High fidelity Taq enzyme AccuTaq ${ }^{\text {Tn }}$ LA DNA Polymerase (Sigma-Aldrich, Shanghai, China) was used for PCR in this study. For each reaction $1 \mu$ of extracted DNA/ RNA sample was used as template. The primers were designed in this study and the PCR cycles were the same for all primer pairs, which included a cycle of $95{ }^{\circ} \mathrm{C}$ for 3 min, 15 cycles of $95{ }^{\circ} \mathrm{C}$ for 30 s, $65^{\circ} \mathrm{C}$ for 30 s (decreasing $1{ }^{\circ} \mathrm{C}$ each cycle) and $72{ }^{\circ} \mathrm{C}$ for 2 min, 15 cycles of $95{ }^{\circ} \mathrm{C}$ for $30 \mathrm{~s}, 51{ }^{\circ} \mathrm{C}$ for $30 \mathrm{~s}$, and $72{ }^{\circ} \mathrm{C}$ for $2 \mathrm{~min}$, and a final cycle of $72{ }^{\circ} \mathrm{C}$ for $10 \mathrm{~min}$. The PCR products were electrophoresed on agarose gels and DNA bands with expected sizes were excised from the gels. The DNA purified from the gels was cloned into plasmid vector pMD18-T (Takara, Dalian, China). Three clones of each recombinant plasmid were sequenced on both stands by

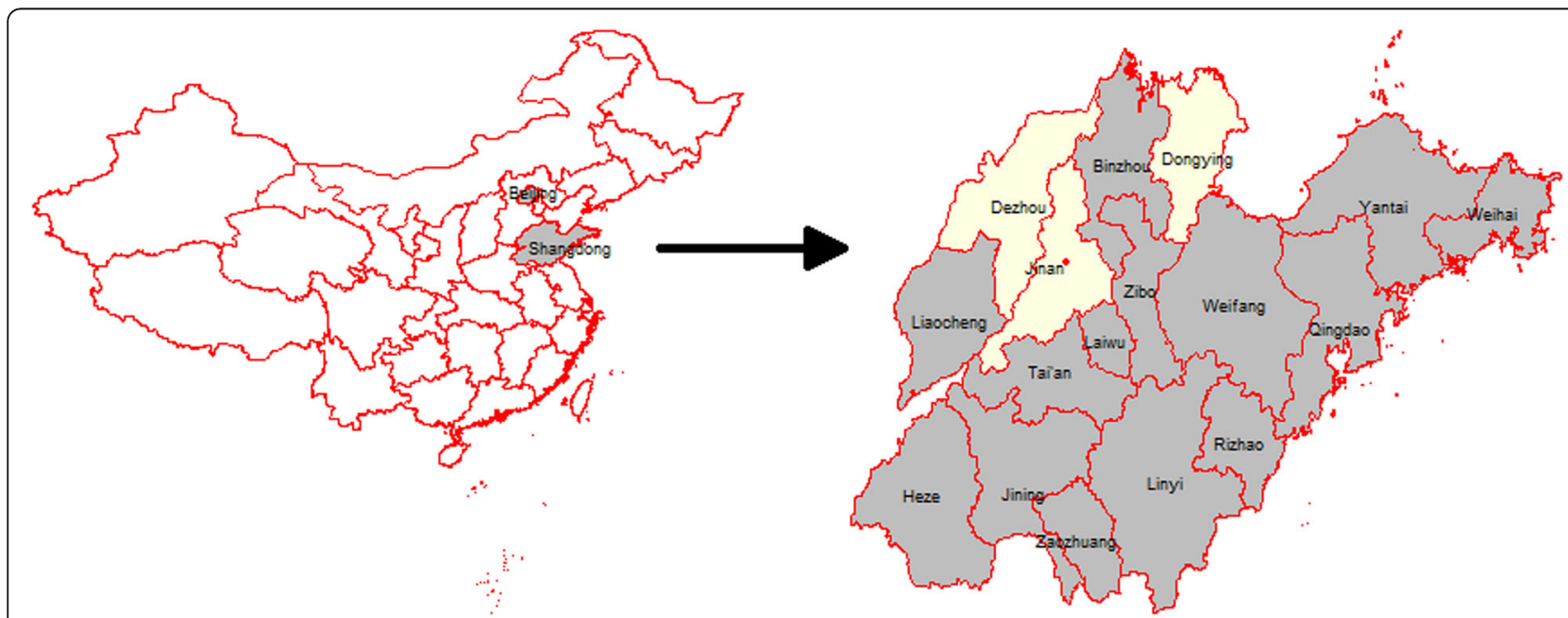

Fig. 1 Geographic location of Shandong Province of China (left) and the mink sample collection sites (right). Mink samples were collected from 14 (grey areas) of 17 cities in Shandong Province. The maps were drawn using the R Project for Statistical Computing (https://www.r-project.org/) 
Table 1 Primers amplification of the entire CDS of $\mathrm{gC}, \mathrm{gD}, \mathrm{gH}, \mathrm{gE}$, and TK genes of PRV

\begin{tabular}{|c|c|c|c|c|c|}
\hline Primers & Sequence & Position (bp) & Length (bp) & Annealing temperature & GenBank accession \\
\hline $\mathrm{gB}-\mathrm{F}$ & CTGGTGGCGGTCTTAGGCG & $8-27$ & 2738 & 60 & KJ526439 \\
\hline$g B-R$ & CTACAGGGCGTCGGGGTCC & $2726-2744$ & & & \\
\hline$g C-F$ & GCTCGTGCAGGCGTACGT & $53,326-53,343$ & 1625 & 55 & AF158090 \\
\hline$g C-R$ & GCGGTCGTTTATTGATTCGG & $54,950-54,931$ & & & \\
\hline gD-F & CCCAGGTTCCCATACACTCAC & $121,236-121,256$ & 1258 & 55 & AF086702 \\
\hline gD-R & TACTGCGGAGGCTACGGAC & $122,487-126,469$ & & & \\
\hline$g \mathrm{E}-\mathrm{F}$ & AGACCATGCGGCCCTTTC & $122,353-122,370$ & 2710 & 58 & AY249861 \\
\hline$g E-R$ & ACGACCACTCCGTGTCCAGC & $125,090-125,071$ & & & \\
\hline $\mathrm{gH}-\mathrm{F}$ & GGAGATGGGGGTGTGACC & $59,631-59,648$ & 3108 & 53 & M61196 \\
\hline $\mathrm{gH}-\mathrm{R}$ & GCGGCAGACACTITAACTCTTG & $62,701-62,680$ & & & \\
\hline TK-F & AGGCGTTCGTAGAAGCGGT & $59,195-59,213$ & 1147 & 56 & AY217095 \\
\hline TK-R & GGGCACGGCAAACTITATTG & $60,340-60,321$ & & & \\
\hline
\end{tabular}

the Biotechnology Research Center, Shandong Academy of Agricultural Sciences (Jinan, China).

\section{Phylogenetic analysis}

In order to get comparable phylogenetic results for all genes, we only selected sequences for viruses that had complete genome sequences in GenBank to do phylogenetic analysis. The DNA sequences were aligned using the Clustal W program implemented in the MEGA7.0 software. The phylogenetic trees that reflected evolutionary distances were constructed using the Maximum-likelihood method employing a Kimura 2-parameter model for nucleotides reconstructed using the same software [18].

\section{Bacterial culture}

The tissues of the brains and livers of minks were scratched with a bacterial inoculation loop and inoculated onto trypsin soy agar plates and blood agar plates. The plates were incubated at $37^{\circ} \mathrm{C}$ for $48 \mathrm{~h}$ under aerobic and anaerobic conditions.

\section{Isolation of virus}

The frozen brain and liver samples from the minks were homogenized, centrifuged at $7168 \mathrm{x}$ g for $10 \mathrm{~min}$ at $4{ }^{\circ} \mathrm{C}$, filtered through disposable filters with an average pore diameter of $0.22 \mu \mathrm{m}$ and transferred to a Vero cell monolayer. The cells were cultured in DMEM supplemented with $2 \%$ fetal bovine serum at $37{ }^{\circ} \mathrm{C}$ and $5 \% \mathrm{CO}_{2}$ condition for $72 \mathrm{~h}$. The cultures were then harvested and repeatedly frozen and thawed three times. The suspension was used for passages on Vero cells. On the third passage of the cell cultures, the supernatant was tested with PCR using the PRV gB gene primers to determine infection with PRV.

\section{Results}

Bacterial pathogen detection

To determine whether the minks died of bacterial infection, their brain and liver tissue smears were stained by Gram staining and examed by microscopy. No bacterium was observered in these tissues from the Gram stain. Additionally, brain and liver samples of each mink were cultured on tryptic soy agar plates and blood agar plates. No bacterium was obtained from brain and liver tissues, suggesting that the minks were not infected with a bacterial pathogen.

PRV as the causative agent of the mink outbreak

PCR amplification of PRV gE gene indicated that $100 \%$ (10/10) minks from the farm were positive to PRV with all organs tested incluing heart, liver, spleen, lung, kidney, brain and intestine. However, none of the organs was positive to other viruses including influenza virus, Parvovirus, rotavirus and porcine circovirus by PCR or RT-PCR amplification.

\section{Prevalence of minks to PRV}

After demonstrating that the dead minks from the farm were infected with PRV, we further collected samples of 566 dead minks in 14 mink farms according to the $95 \%$ confidence level and 10\% PRV infection rate. PCR amplification of gE gene showed that 5.8\% (33/566) of minks were positive to PRV.

\section{Isolation of PRV from minks}

To further determine the characteristics of PRV in the minks, we isolated PRV from mink tissues. On the third passage of the mink sample innoculated cell cultures, the supernatant of the culture was amplifed with PCR by using the gB gene primers. PCR amplification indicted that cells derived from two mink samples were positive. The viruses were named W-MPRV1 and W-MPRV2, 
respectively. Strain W-MPRV1 was isolated from the sample of a dead mink from the farm with outbreak of pseudorabies and W-MPRV2 was isolated from a dead mink from another farm during the epidemilogic investigation.

\section{Mink PRV sequence analysis}

The entire coding region plus the $5^{\prime}$ and $3^{\prime}$ end of non-coding regions of gB (2735 bp), gC (1624 bp), gD (787 bp), gE (2724 bp), gH (3262 bp) and TK (1157 bp) of the PRV strains W-MPRV1 and W-MPRV2 were sequenced based on the PCR products of each gene. The DNA sequences of two genes ( $\mathrm{gB}$ and TK) were 100\% identical between the two mink PRV strains. The DNA sequence homology of three genes between the two mink PRV strains ( $\mathrm{gC}$, gE, and $\mathrm{gH}$ ) were $99.8 \%$ to 99.9\%. BLAST analysis indicated that homology of the strains W-MPRV1, W-MPRV2 and Chinese PRV isolates DL14/08(GenBank accession: KU360259), HNX (KM189912), HNB(KM189914), HN1201 (KP722022), HeN1(KP098534), TJ (KJ789182) were $99.9 \%$ to $100 \%$ for the 6 genes. The gD gene of strain W-MPRV1 was identical to strain W-MPRV2 and the Chinese PRV isolates on the $5^{\prime}$ end, but missed a 281 bp near the $3^{\prime}$ end of the gene compared to strain W-MPRV2 and the Chinese PRV isolates in GenBank (Fig. 2). The deletion

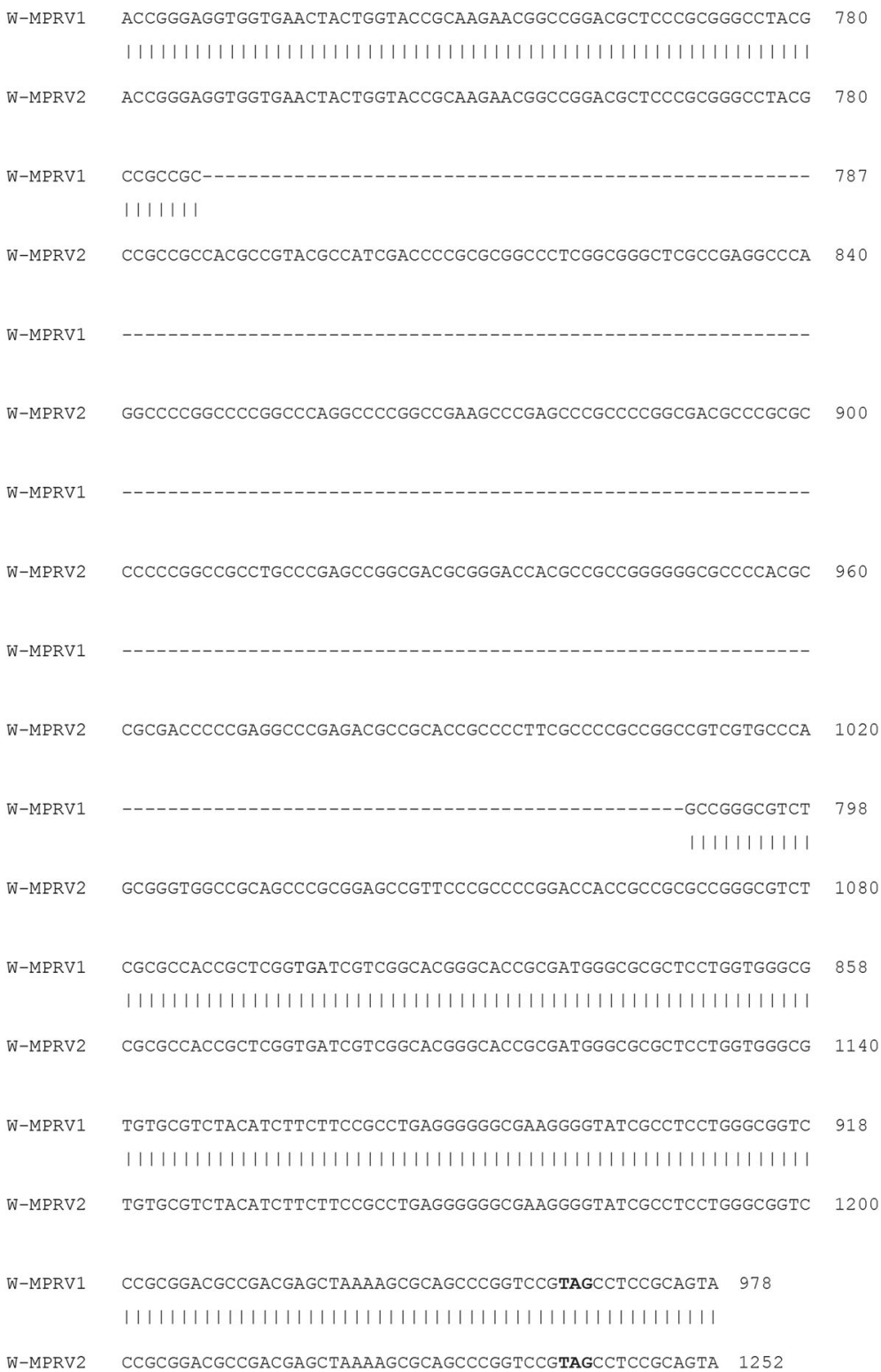

Fig. 2 DNA sequence alignment of gD gene of mink isolates of PRV W-MPRV1 and W-MPRV2. W-MPRV1 had a deletion of 281 nucleotides from 787 nucleotide to 1069 nucleotide 
of 281 nucleotides in the gD gene of W-MPRV1 caused a frameshift mutation and generated a protein with a deletion of 93 amino acids near the C-terminal (Fig. 3). The sequences generated in this study were deposited in GenBank (Accession numbers: MF940933 - MF940944).

\section{Phylogenetic analysis}

Phylogenetic analysis with each individual gene and the concatenated sequence of $\mathrm{gB}, \mathrm{gC}, \mathrm{gD}, \mathrm{gE}$ and $\mathrm{TK}$ genes showed similar results and only the phylogenetic trees of gB gene and the concatenated sequence were shown in Fig. 4. The PRV strains were classified into two branches with all 6 genes or the concatenated sequences with the Chinese isolates in one branch represented by strains W-MPRV1 and W-MPRV2 and the American and European isolates in another branch represented by Becker strain (Fig. 4).

\section{Discussion}

In this study we investigated the causative agent of an outbreak of a fatal acute infectious disease in minks in a farm in Shandong Province of China, which caused a large scale of mink death with $100 \%$ cases fatality $(3522$ /3250) and $87.2 \%(3522 / 4028)$ mortality. We first screened the minks by PCR for pseudorabies virus, influenza virus, Parvovirus, rotavirus and porcine circovirus.
Except for pseudorabies virus, all other viruses were negative in the mink samples. Our results indicated that PRV caused the outbreak of minks in the farm. To investigate whether PRV infection is widely distributed in Shandong Province, we subsequently collected samples of 566 minks from 14 farms in 14 cities of Shandong Province and amplified the gE gene with PCR. We found that $5.8 \%$ of 566 dead minks from all over Shandong Province were PCR positive to PRV. Our results further suggest that PRV infection of minks is widely spread in mink populations in Shandong Province.

We isolated two strains of pseudorabies virus from two dead minks from the farms. W-MPRV1 strain was isolated from a mink from the farm with pseudorabies outbreak and W-MPRV2 strain was isolated from a mink obtained in the subsequent epidemiologic investigation from another farm. Strains W-MPRV1 and WMPRV2 were highly homologous, but not identical based on DNA sequences. They have identical sequences on $\mathrm{gB}$ and TK genes and $99.8 \%$ to $99.9 \%$ homology on $\mathrm{gC}, \mathrm{gE}$, and $\mathrm{gH}$ gene. The major difference between these two strains is that W-MPRV1 has a 281 bp deletion near the 3 end of the gD gene that generates a frameshift in $\mathrm{gD}$ gene resulting in a protein missing 93 amino acid near the C-terminal. Apparently the mutation in $\mathrm{gD}$ did not affect the virulence of W-MPRV1 to

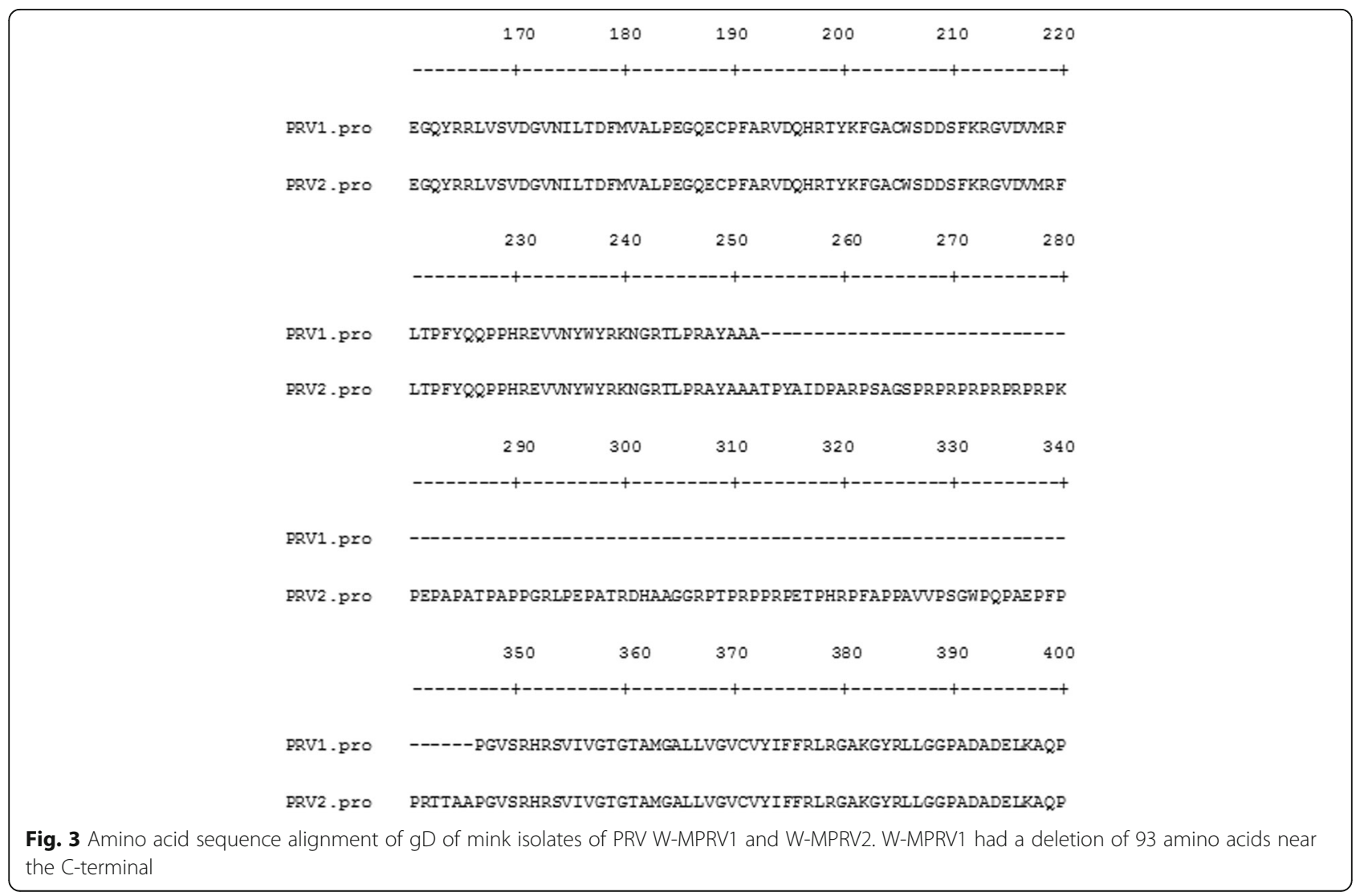




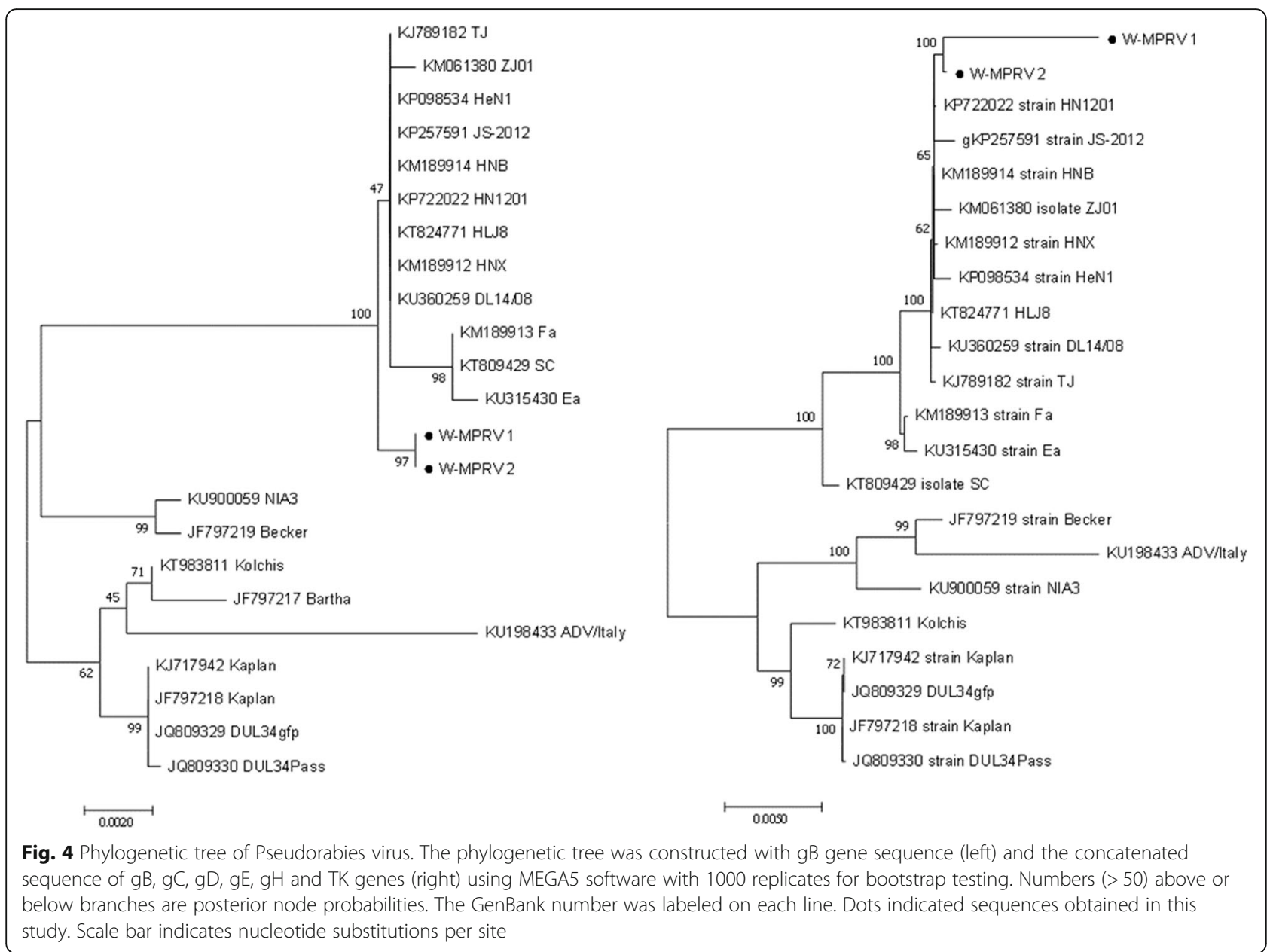

minks because it was isolated from a mink died in the outbreak. The gD of PRV is the viral ligand required for entry of extracellular particles [19, 20]. We do not know if the mutation generated a functional protein or not.

PRV strains from minks in this study are in the same phylogenetic clade with porcine PRV strains from China. This indicated that the mink PRV is a strain of porcine PRV. Among pigs, PRV is transmitted by contaminated secretions, excretions, aerosols, and venereal route [21]. No pig was present in the mink farm where PRV was isolated in this study and the farm was not near any pig farms. It is most likely the minks acquired PRV from meat products. A recent report indicated that farm raised foxes and domesticated dogs were infected with PRV transmitted by pork offal in China [22, 23]. A less likely possibility is that minks acquired PRV through long distance transmissions from aerosols because PRV can be transmit via the air [24]. In recent years porcine PRV infection has been a problem for pig farms in China. Bartha-K61 vaccine has been used worldwide to eradicate PRV [25]. Bartha-K61 vaccination provided complete protection against infection by the classic PRV
SC strain. However, since late 2011 several highly virulent PRV strains including strains HeN1, JS-2012, and TJ have been isolated in various parts of China and the disease caused by these PRV strains is characterized by neurologic symptoms and a high mortality rate in pigs [25-27]. In protection assays, Bartha-K61 vaccine provided only partial protection against infection by strains HeN1, JS-2012, and TJ, suggesting that Bartha-K61 vaccine does not provide effective protection against new PRV strain infections in China [25-27]. The PRV strain isolate from minks in this study is phylogenetically closely related to the Bartha-K61 vaccine-resistant PRV strains, suggesting that vaccine-resistant PRV has spread widely throughout China and can cause a variety of animal infections. Eradicating pseudorabies in China under these circumstances proves challenging.

Shandong Province has the largest fur industry in China, which annually produces more than $50 \%$ of fur animals in China. In 2011, more than 30 million minks were raised in Shandong Province, with an annual increase of $20-40 \%$ [28]. This study indicated that PRV is widely distributed and can cause deadly outbreaks in 
minks in Shandong Province. Therefore, PRV infection of minks should be monitored and controlled in Shandong Province. Minks are primary fed fish and chicken products in Shandong Province. The source of PRV infected minks in Shandong Province is not clear. We also do not know whether PRV can establish persistent or prolonged infection in minks.

\section{Conclusions}

We suggested that pseudorabies virus could cause an outbreak of minks in a farm in Shandong Province of China and the virus has a very high infection rate in minks in Shandong Province, which is a challenge for the fur industry in China.

\section{Abbreviation}

PRV: Pseudorabies virus

\section{Acknowledgements}

We are grateful to Hao Yu (Fudan University School of Medicine) for reading the manuscript, to Xiang-rong Qin and Jian-Wei Liu (Wuhan University School of Health Sciences) for phylogenetic analysis.

\section{Funding}

This work was supported in part by a grant from the Shandong Provincial Modern Agricultural Industry Technology System (\#SDAIT-21-05), a grant from Shandong Province Science and Technology Development Program (2014GSF121004), a grant from Shandong Agricultural Science and Technology Innovation Project (CXGC2016B14), and a grant from the National Nature Science Foundation of China (31570167). The funding bodies have no role in the design or conclusion of the study.

\section{Availability of data and materials}

All data generated or analyzed during this study are included in this published article.

\section{Authors' contributions}

GSW, FLT, and JBW participated in the design of the study. GSW, YJD, JQW planned and performed the experiments. GSW and XJY analyzed the data and contributed to write the manuscript. All authors read and approved the final manuscript.

\section{Ethics approval}

The animal experiments were approved by the Bioethic Committee of Shandong University (Permit Number: SYXK (Shandong Province) 20140011 ). This study was conducted in strict accordance with the rules of the Bioethic Committee of Shandong University. The farmers participated in this study provided oral informed consent.

\section{Consent for publication}

Not applicable.

\section{Competing interests}

The authors declare that they have no competing interests.

\section{Publisher's Note}

Springer Nature remains neutral with regard to jurisdictional claims in published maps and institutional affiliations.

\section{Author details}

'Shandong Provincial Center for Animal Disease Control and Prevention, Jinan, China. ${ }^{2}$ School of Life Sciences, Shandong University, 27 Shanda Road South, Jinan 250100, China. ${ }^{3}$ Shandong Key Laboratory of Animal Disease Control and Breeding, Institute of Animal Science and Veterinary Medicine, Shandong Academy of Agricultural Sciences, Jinan, China. ${ }^{4}$ School of Health Science, Wuhan University, Wuhan, China.
Received: 14 February 2017 Accepted: 3 January 2018

Published online: 19 January 2018

\section{References}

1. Marcaccini A, López Peña M, Quiroga Ml, Bermúdez R, Nieto JM, Alemañ N. Pseudorabies virus infection in mink: a host-specific pathogenesis. Vet Immunol Immunopathol 2008;124(3-4):264-73. https://doi.org/10.1016/j. vetimm.2008.03.013. Epub 2008 Apr 8. PubMed PMID: 18490062.

2. Pensaert M, Kluge JP. Pseudorabies virus (Aujeszky's disease). In: Pensaert MB, editor. Virus infections of Porcines. Amsterdam: Elsevier; 1989. p. 39-65.

3. Wohlgemuth $K$, Leslie PF, Reed DE, Smidt DK. Pseudorabies virus associated with abortion in swine. J Am Vet Med Assoc 1978;172(4):478-479. PubMed PMID:203566.

4. Wu R, Bai C, Sun J, Chang S, Zhang X. Emergence of virulent pseudorabies virus infection in northern China. J Vet Sci. 2013;14(3):363-365. PubMed PMID: 23820207; PubMed Central PMCID: PMC3788163.

5. van Oirschot JT. Diva vaccines that reduce virus transmission. J Biotechnol 1999: 73(2-3):195-205. Review. PubMed PMID: 10486928.

6. Davidson RM. Control and eradication of animal diseases in New Zealand. N Z Vet J 2002:50(3 Suppl):6-12. PubMed PMID: 16032229.

7. Moynagh J. Aujeszky's disease and the European Community. Vet Microbiol 1997:55(1-4):159-66. PubMed PMID: 9220609.

8. Müller T, Bätza HJ, Schlüter H, Conraths FJ, Mettenleiter TC. Eradication of Aujeszky's disease in Germany. J Vet Med B Infect Dis Vet Public Health 2003;50(5):207-13. PubMed PMID: 12864894.

9. Anderson LA. Pseudorabies (Aujeszky's disease) and its eradication: a review of the US experience 2008. United States Department of Agriculture, animal and plant health inspection service., 2008.

10. Sun Y, Luo Y, Wang CH, Yuan J, Li N, Song K, Qiu HJ. Control of swine pseudorabies in China: opportunities and limitations. Vet Microbiol 2016; 183:119-24. https://doi.org/10.1016/j.vetmic.2015.12.008. PubMed PMID: 26790944.

11. Marcaccini A, López Peña M, Quiroga Ml, Bermúdez R, Nieto JM, Alemañ N. Pseudorabies virus infection in mink: a host-specific pathogenesis. Vet Immunol Immunopathol 2008;124(3-4):264-73. https://doi.org/10.1016/j. vetimm.2008.03.013. PubMed PMID: 18490062

12. Pensaert M, Kluge JP. Pseudorabies virus (Aujeszky's disease). In: Pensaert MB. (Ed.) (1989) Virus infections of Porcines.Elsevier, Amsterdam: 39-65

13. Klupp BG, Hengartner CJ, Mettenleiter TC, Enquist LW. Complete, annotated sequence of the Pseudorabies virus genome. J Virol. 2004;78:424-40.

14. Yin Z. In: Liu JH, editor. Animal Virology. Beijing: Science Press; 1997. p. 1000-1.

15. Liu H, Li XT, Hu B, Deng XY, Zhang L, Lian SZ, Zhang HL, Lv S, Xue XH, Lu $R G$, Shi N, Yan MH, Xiao PP, Yan XJ. Outbreak of severe pseudorabies virus infection in pig-offal-fed farmed mink in Liaoning Province, China. Arch Virol 2017;162(3):863-866. https://doi.org/10.1007/s00705-016-3170-7. PubMed PMID: 27885561

16. Christodoulou T, Tsiroyiannis E, Papadopoulos O, Tsangaris T. An outbreak of Aujeszky's disease in minks. Cornell Vet 1970;60(1):65-73. PubMed PMID: 5434273.

17. Wang GS, Sun N, Tian FL, Wen YJ, Xu C, Li J, Chen Q, Wang JB. Genetic analysis of porcine circovirus type 2 from dead minks. J Gen Virol 2016:97(9): 2316-22. https://doi.org/10.1099/jgv.0.000529. PubMed PMID: 27324162.

18. Kumar S, Stecher G, Tamura K. MEGA7: molecular evolutionary genetics analysis version 7.0 for bigger datasets. Mol Biol Evol 2016 Jul;33(7):1870-4. https://doi.org/10.1093/molbev/msw054. Epub 2016 Mar 22. PubMed PMID: 27004904

19. Ch'ng TH, Spear PG, Struyf F, Enquist LW. Glycoprotein D-independent spread of pseudorabies virus infection in cultured peripheral nervous system neurons in acompartmented system. J Virol 2007;81(19):10742-57. PubMed PMID: 17652377; PubMed Central PMCID: PMC2045490.

20. Farnsworth A, Goldsmith K, Johnson DC. Herpes simplex virus glycoproteins $\mathrm{gD}$ and $\mathrm{gE} / \mathrm{gl}$ serve essential but redundant functions during acquisition of the virion envelope in the cytoplasm. J Virol 2003;77(15):8481-94. PubMed PMID:12857917: PubMed Central PMCID: PMC165244.

21. Romero CH, Meade PN, Shultz JE, Chung HY, Gibbs EP, Hahn EC, Lollis G. Venereal transmission of pseudorabies viruses indigenous to feral swine. J Wildl Dis 200137(2):289-96. PubMed PMID: 11310879.

22. Jin HL, Gao SM, Liu Y, Zhang SF, Hu RL. Pseudorabies in farmed foxes fed pig offal in Shandong province, China. Arch Virol 2016161(2):445-8. https:// 
doi.org/10.1007/s00705-015-2659-9. Epub 2015 Nov 13. PubMed PMID 26563317.

23. Zhang L, Zhong C, Wang J, Lu Z, Liu L, Yang W, Lyu Y. Pathogenesis of natural and experimental Pseudorabies virus infections in dogs. Virol J 2015: 12:44. https://doi.org/10.1186/s12985-015-0274-8. PubMed PMID: 25889104; PubMed Central PMCID: PMC4374540.

24. Christensen LS, Mousing J, Mortensen S, Soerensen KJ, Strandbygaard SB, Henriksen CA, Andersen JB. Evidence of long distance airborne transmission of Aujeszky's disease (pseudorabies) virus. Vet Rec 1990;127(19):471-4. PubMed PMID: 1980166.

25. An TQ, Peng JM, Tian ZJ, Zhao HY, Li N, Liu YM, Chen JZ, Leng CL, Sun Y, Chang D, Tong GZ. Pseudorabies virus variant in Bartha-K61-vaccinated pigs, China, 2012. Emerg Infect Dis 2013;19(11):1749-55. https://doi.org/10.3201/ eid1911.130177. PubMed PMID: 24188614; PubMed Central PMCID: PMC3837674.

26. Tong W, Liu F, Zheng H, Liang C, Zhou YJ, Jiang YF, Shan TL, Gao F, Li GX, Tong GZ. Emergence of a Pseudorabies virus variant with increased virulence to piglets. Vet Microbiol 2015;181(3-4):236-40. https://doi.org/10. 1016/j.vetmic.2015.09.021. Epub 2015 Sep 30. PubMed PMID: 26507829.

27. Luo Y, Li N, Cong X, Wang CH, Du M, Li L, Zhao B, Yuan J, Liu DD, Li S, Li Y, Sun Y, Qiu HJ. Pathogenicity and genomic characterization of a pseudorabies virus variant isolated from Bartha-K61-vaccinated swine population in China. Vet Microbiol 2014;174(1-2):107-15. https://doi.org/10. 1016/j.vetmic.2014.09.003. PubMed PMID: 25293398.

28. Wang GZ, Qing MJ, Zhang W. Shandong Province fur animal breeding industry problems and countermeasure strategy. Shangdong J Anim Sci Vet Med. 2014;35(8):21-2.

\section{Submit your next manuscript to BioMed Central and we will help you at every step:}

- We accept pre-submission inquiries

- Our selector tool helps you to find the most relevant journal

- We provide round the clock customer support

- Convenient online submission

- Thorough peer review

- Inclusion in PubMed and all major indexing services

- Maximum visibility for your research

Submit your manuscript at www.biomedcentral.com/submit
Biomed Central 